\title{
PERBANDINGAN PENGELOLAAN SUMBER DAYA MANUSIA DALAM ORGANISASI PEMERINTAH DAN NON PEMERINTAH
}

\author{
Meita Santi Budiani \\ Program Studi Psikologi Universitas Negeri Surabaya \\ e-mail:itappha@yahoo.com
}

\begin{abstract}
Abstrak: Artikel ini dibuat untuk membandingkan antara pengelolaan sumber daya manusia dari organisasi pemerintah dan non pemerintah. Data mengenai pengelolaan Sumber Daya Manusia (SDM) pada organisasi pemerintah diperoleh dari BPOM Jakarta melalui literatur dan disertai data pendukung dari hasil wawancara terhadap Kabag kepegawaian BPOM dan Pemprov DKI tahun 2008. Hasil analisis menunjukkan bahwa terdapat kesamaan di antara keduanya, yaitu penekanan pada peningkatan efisiensi, efektivitas kerja, serta garis besar pengelolaan SDM, seperti fungsi dan kewajiban tenaga kerja, dan penekanan pada kinerja dan kompetensi tenaga kerja. Adapun perbedaannya antara lain dalam hal sumber dana pelaksanaan pengelolaan SDM, pengelolaan SDM yang spesifik, seperti masalah kenaikan pangkat dan pemutusan hubungan kerja, serta struktur organisasi..
\end{abstract}

Kata kunci: Persepsi kualitas layanan, minat membeli, konsumen.

Manajemen kepegawaian dan sumber daya manusia sangat penting bagi perusahaan dalam mengelola, mengatur, dan memanfaatkan pegawai sehingga dapat berfungsi secara produktif untuk tercapainya tujuan perusahaan. Sumber daya ini perlu dikelola secara profesional agar terwujud keseimbangan antara kebutuhan pegawai dengan tuntutan dan kemampuan organisasi perusahaan. Keseimbangan tersebut merupakan kunci utama perusahaan agar dapat berkembang secara produktif dan wajar, karena perkembangan usaha dan organisasi perusahaan sangatlah bergantung pada produktivitas tenaga kerja yang ada.

Pengelolaan pegawai secara profesional ini harus dimulai sejak perekrutan pegawai, penyeleksian, pengklasifikasian, penempatan pegawai sesuai dengan kemampuan, penataran, dan pengembangan karirnya. Dalam suatu perusahaan, masalah tersebut sudah menjadi hal yang umum, sehingga jika banyak pegawai yang sebenarnya secara potensi berkemampuan tinggi tetapi tidak mampu berprestasi dalam kerja, hal tersebut dapat disebabkan kondisi psikologis dari jabatan yang tidak cocok, atau lingkungan tempat kerja tidak membawa rasa aman bagi dirinya. Jika hal ini terjadi, maka dapat menimbulkan kerugian bagi perusahaan. Oleh karena itu, faktor manusia merupakan modal utama yang perlu diperhatikan oleh pengusaha atau pemimpin perusahaan.

Penyelesaian masalah yang berkaitan dengan manusia sebagai tenaga kerja, seringkali memerlukan keahlian khusus, sehingga bidang pengelolaan Sumber Daya Manusia semakin pesat perkembangannya, salah satunya melalui penelitian dan wacana, yang diterapkan secara praktis dalam organisasi atau perusahaan.

Wardhana dalam Munandar (2001) mengatakan bahwa istilah sumber daya manusia (SDM) mencakup semua energi, ketrampilan, bakat dan pengetahuan manusia yang dipergunakan untuk tujuan produksi dan jasa-jasa yang bermanfaat. Munandar (2001) juga melihat bahwa dalam memandang manusia sebagai tenaga kerja, pendekatan SDM melihat manusia sebagai mahluk yang menghendaki perkembangan, manusia yang menginginkan kegiatan-kegiatan sesuai dengan kemampuannya dan sebagai mahluk yang berhasrat mengaktualisasikan dirinya. Terdapat beberapa definisi yang dapat menjelaskan mengenai apa itu pengelolaan 
Sumber Daya Manusia (SDM).

Sumber Daya Manusia (SDM) dalam konteks bisnis, adalah orang yang bekerja dalam suatu organisasi yang sering pula disebut karyawan. Sumber Daya Manusia merupakan aset yang paling berharga dalam perusahaan, tanpa manusia maka sumber daya perusahaan tidak akan dapat menghasilkan laba atau menambah nilainya sendiri. Manajemen Sumber Daya Manusia didasari pada suatu konsep bahwa setiap karyawan adalah manusia, bukan mesin, dan bukan semata menjadi sumber daya bisnis. Manajemen Sumber Daya Manusia berkaitan dengan kebijakan dan praktek-praktek yang perlu dilaksanakan oleh manajer, mengenai aspek-aspek Sumber Daya Manusia dari Manajemen Kerja. Tidak ada definisi yang sama tentang Manajemen Sumber Daya Manusia (MSDM). Tiga (3) definisi sebagai perbandingan dapat dikemukakan.

Menurut Amstrong (1994), MSDM adalah bagaimana orang-orang dapat dikelola dengan cara yang terbaik dalam kepentingan organisasi. Kenooy (1990), mengemukakan manajemen SDM sebagai suatu metode memaksimalkan hasil dari sumber daya tenaga kerja dengan mengintergrasikan MSDM ke dalam strategi bisnis. Sedangkan Storey (1995) menyatakan MSDM sebagai suatu pendekatan yang khas, terhadap manajemen tenaga kerja yang berusaha mencapai keunggulan kompetitif, melalui pengembangan strategi dari tenaga kerja yang mampu dan memiliki komitmen tinggi dengan menggunakan tatanan kultur yang terintegrasi, struktural, dan teknik-teknik personel (dalam Dessler, 1997; Klieman, 2000).

Terdapat berbagai kegiatan dalam pengelolaan sumber daya manusia di dalam organisasi/perusahaan. Menurut Cherrington (1983) dalam Thornton (1992), Pengelolaan Sumber Daya Manusia memiliki beberapa fungsi di dalam organisasi, antara lain adalah: Rekrutmen (Recruitment, Seleksi (Selection), Penempatan (Placement), Pelatihan dan Pengembangan (Training and Development),
Penilaian Kinerja (Performance Appraisal), Pengembangan Organisasi (Organization Develompent), Perencanaa SDM (Human Resouces Planning), Promosi dan Mutasi Karyawan (Promotion and Transfer), dan Layoffs

Rekrutmen (Recruitment). Dalam rekrutmen, pengelola SDM bertugas untuk menjaring individu-individu berbakat untuk menempati posisi-posisi yang dibutuhkan di dalam organisasi/perusahaan. Sumbernya dapat diperoleh dari luar organisasi maupun dari dalam organisasi.

Seleksi (Selection). Pada proses seleksi, fungsi dari pengelolaan SDM adalah memutuskan dari sejumlah kandidat, mana yang akan terpilih dan mana yang tidak diterima untuk menempati posisi yang tersedia di organisasi.

Penempatan (Placement). Pada penempatan, pengelola SDM bertugas menempatkan seorang pekerja di posisi yang sesuai dengan kompetensi dan aspek-aspek yang dimilikinya. Selain itu juga harus memperhatikan kemungkinan apakah orang yang bersangkutan dapat berkembang di posisi tersebut.

Pelatihan dan Pengembangan (Training and Development). Dalam proses pelatihan dan pengembangan, pengelolaan SDM berfungsi untuk memberikan informasi dan pengetahuan kepada karyawan mengenai ketrampilan, kemampuan, karakteristik atau hal-hal lain yang dibutuhkan oleh individu berkaitan dengan tercapainya efektifitas organisasi.

Penilaian Kinerja (Performance Appraisal). Pengelolaan SDM juga berfungsi untuk mengatur dan membuat prosedur dalam rangka mengevaluasi kinerja karyawannya.

Pengembangan Organisasi (Organization Develompent). Dalam pengembangan organisasi, pengelolaan SDM berfungsi untuk menciptakan prosedur untuk meningkatkan efektifitas suatu departemen atau divisi di dalam organisasi atau organisasi secara keseluruhan. 
Perencanaa SDM (Human Resouces Planning). Pengelola SDM juga harus mampu meramalkan tuntutan yang akan terjadi serta meramalkan kompetensi-kompetensi yang nantinya harus dimiliki oleh tenaga kerja, sehingga dapat dilakukan pengembangan / tindakan perencanaan sejak dini.

Promosi dan Mutasi Karyawan (Promotion and Transfer). Dalam promosi dan mutasi karyawan, pengelolaan SDM berfungsi untuk menempatkan tenaga kerja yang dinilai sesuai pada pekerjaan baru dengan tingkat tanggung jawab yang lebih tinggi dan jenis pekerjaan yang lebih kompleks dan kompensasi yang lebih baik (kenaikan jabatan). Selain itu pengelolaan SDM juga berfungsi untuk menilai dan mengatur prosesnya jika ada karyawan yang memiliki minat bekerja di divisi lain atau di lokasi lain.

Layoffs . Pengelola SDM juga berfungsi untuk mengatur serta menentukan pekerja mana yang tidak akan dipertahankan dan pekerja mana yang akan dipertahankan.

\section{Pengelolaan Sumber Daya Manusia dalam Organisasi Pemerintah}

Organisasi pemerintah adalah organisasi yang bergerak dan bekerja untuk pemerintah demi kepentingan negara dan masyarakat dalam hal ini pemerintah, negara dan masyarakat Indonesia. Organisasi ini merupakan bagian dari pemerintah, birokrasi ataupun negara yang terdiri dari depatemen dan non departemen. Resources untuk operasional dari lembaga atau institusi pemerintah adalah merupakan tanggung jawab pemerintah, termasuk juga sumber daya manusia di dalamnya.

Berdasarkan hasil wawancara dengan Kepala Biro Perencanaan dan Keuangan Badan Pemeriksa Obat dan Makanan yang notabene merupakan salah satu lembaga pemerintah di Indonesia, diketahui bahwa sumber dana untuk biaya operasional institusi-institusi pemerintah berasal dari
APBN atau APBD. Termasuk juga untuk pembayaran imbal jasa bagi Pegawai Negeri Sipil yang bekerja untuk institusi pemerintahan tersebut. Selain itu terlihat juga bahwa kebanyakan organisasi pemerintah memiliki struktur organisasi yang bersifat birokrasi dengan kewenangan yang terpusat dengan jarak kontrol yang sempit serta adanya proses pengambilan keputusan yang mengikuti rantai komando (keputusan yang diambil oleh bagian organisasi yang lebih rendah, harus mendapat persetujuan dari bagian atasnya).

Dalam organisasi dengan struktur birokrasi ini dapat bekerja tenaga-tenaga yang tidak perlu memiliki kompetensi dan kemampuan yang tinggi, karena pelaksanaan tugas sudah mengikuti peraturan-peraturan yang telah diformalisasi dan distandarisasi.

Selain gaji pokok, PNS juga mendapatkan tunjangan-tunjangan lain baik yang berupa uang maupun bukan uang seperti tunjangan kesehatan (melalui ASKES), tunjangan beras (dalam bentuk uang) dll (Kabag Kepegawaian Pemprov DKI, 2008).

Hadiat (2005) menyebutkan bahwa rigiditas atau kekakuan struktural yang cenderung birokratis mewarnai lembaga litbang (penelitian dan pembangunan) pemerintah dan pada kondisi tertentu memasung kemandirian dan kreativitas. Kondisi tersebut berakibat kurang kondusifnya iklim inovasi dan kemandegan kemampuan (ide capacity), sehingga produktivitas institusi litbang tidak optimal. Kekakuan tersebut muncul berkaitan dengan aturan main kelembagaan pemerintah dan sistem pengelolaan anggaran yang berdampak pada rutinitas kerja institusi litbang.

Pengelolaan manajemen pada organisasi/institusi pemerintah lebih diarahkan untuk menjamin penyelenggaraan tugas pemerintahan dan pembangunan secara berhasil guna dan berdayaguna (Kabag Kepegawaian Pemprov DKI, 2008). Secara khusus, pengelolaan SDM (Pegawai Negeri Sipil) di institusi/organisai pemerintah adalah 
keseluruhan upaya-upaya untuk meningkatkan efisiensi, efektivitas dan derajat profesionalisme penyelenggaraan tugas, fungsi dan kewajiban kepegawaian, yang meliputi perencanaan, pengadaan, pengembangan kualitas, penempatan, promosi, penggajian, kesejahteraan dan pemberhentian.

Kabag Kepegawaian Pemprov DKI, 2008 menyebutkan bahwa pengelolaan SDM di pemerintahan mengacu pada salah satunya Undang Undang Nomor 43 Tahun 1999 yang menyatakan bahwa pengelolaan SDM aparatur pemerintah dilaksanakan dengan basis kinerja. Kinerja ini ditampilkan sebagai hasil sinergi dari skill, knowledge (pengetahuan), dan attitude (perilaku) yang akhirnya membentuk personal qualities (kualitas pribadi) serta terkait erat dengan kompetensi. Kualitas pribadi inilah yang nantinya akan mengarah pada kinerja yang terbaik. dilihat di Gambar 1.

Selain itu, berdasarkan hasil wawancara dengan Kepala Biro Perencanaan dan Keuangan Badan Pemeriksa Obat dan Makanan, diketahui bahwa kenaikan pangkat bagi PNS secara otomatis terjadi setiap 4 tahun sekali. Sehingga sulit untuk memotivasi kinerja PNS dari segi kenaikan pangkat. Karena secara otomatispun, seiringa dengan berjalannya waktu, kenaikan pangkat itu juga akan tetap terjadi.

Untuk memotivasi kinerja pegawainya, institusi pemerintah memberikan penghargaan-penghargaan baik dalam bentuk uang maupun bukan. Salah satu kriteria pemberian penghargaan ini berdasarkan penilaian kinerja dari pegawai yang bersangkutan. Walaupun menurut (Kabag Kepegawaian Pemprov DKI,2008) penilaian tersebut belum cukup efektif karena hasil penilaian rata-rata dari seluruh pegawai

Gambar 1. Prosedur Kenaikan Pangkat

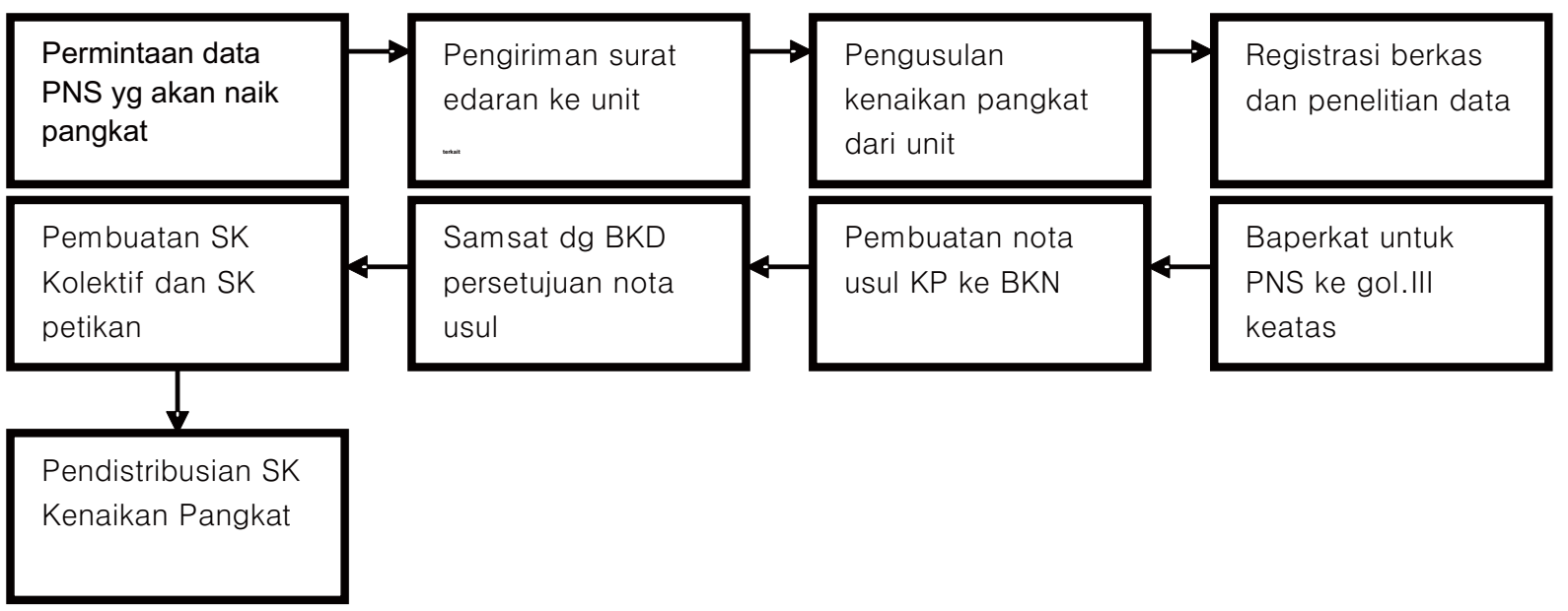

Prosedur kenaikan pangkat pada institusi dan organisasi pemerintah juga terlihat melalui prosedur yang panjang. Seperti yang terjadi pada Pemerintah Proponsi DKI Jakarta (Kabag Kepegawaian Pemprov DKI, 2008), bahwa prosedur itu harus melalui 9 tahapan untuk memperoleh kenaikan pangkat. Tahapan tersebut dapat menunjukkan hasil jauh di atas rata-rata, sehingga dinilai masih belum objektif, tetapidengan memperbaiki prosedur penilaian kinerja yang ada, kemungkinan besar cara ini akan mampu meningkatkan kinerja pegawai di institusi pemerintahan.

Berdasarkan hasil wawancara dengan Kepala Biro Perencanaan dan Keuangan 
Badan Pemeriksa Obat dan Makanan, diketahui bahwa proses Pemutusan Hubungan Kerja pada PNS lebih sulit untuk dilakukan. Hal ini juga ditambahkan oleh (Kabag Kepegawaian Pemprov DKI, 2008) mengenai jenis hukuman terhadap PNS apabila mereka melakukan pelanggaran mengacu pada PP NOMOR 30 tahun 1980. Jenis hukuman terdiri dari hukuman disiplin ringan, yang berupa teguran lisan, teguran tertulis, pernyataan tidak puas secara tertulis; hukuman disiplin sedang, yang berupa penundaan kenaikan gaji (1 tahun), penurunan gaji (1X) kenaikan berkala (1X), penundaan kenaikan pangkat (1 tahun); hukuman disiplin berat, yang berupa penurunan pangkat $<1$ tingkat (1 tahun), pembebasan dari jabatan, pemberhentian dengan hormat, tidak atas permintaan sendiri, pemberhentian tidak dengan hormat. Selain itu (Kabag Kepegawaian Pemprov DKI, 2008) juga menyebutkan bahwa apabila ada PNS yang masuk penjara tidak sampai 4 tahun lamanya, pada saat dibebaskan ia masih dapat bergabung di institusi pemerintahan tempat ia bekerja sebelumnya.

Kabag Kepegawaian Pemprov DKI (2008) juga mengatakan bahwa pengelolaan SDM di institusi pemerintahan sangat terkait erat dengan kebijakan yang dibuat oleh pemerintah. Seperti contoh yang disebutkan bahwa untuk posisi tertentu seperti Dinas lalu lintas, Pemprov DKI hanya memerlukan pegawai dengan status kontrak (karena posisi tersebut hanya membutuhkan tenaga yang kuat dan muda), pengelola SDM sudah merancang planning SDM yang akan menempati posisi tersebut. Tetapi karena kebijakan pemerintah mengatakan bahwa semua pegawai dengan status kontrak harus diangkat menjadi tetap, maka pengelola SDM Pemprov DKI mengalami kesulitan untuk mencarikan posisi bagi pegawai-pegawai yang sudah berkurang tenaganya dan tidak produktif lagi di posisi tersebut. Atau jika mereka tetap dikaryakan untuk jabatan tersebut, akan sulit bagi mereka untuk memberikan hasil kerja yang baik. Dari sini terlihat bahwa pengelola SDM akan sulit melakukan PHK bagi PNS yang dianggap bermasalah dan tidak dapat begitu saja melepas PNS yang tidak lagi baik performa kerjanya.

Kepala Biro Keuangan dan Perencanaan BPOM juga mengatakan bahwa di dalam institusi pemerintahan, terdapat perserikatan yang dinamakan KORPRI (Korps Pegawai Negeri). Perserikatan ini berfungsi untuk menyalurkan aspirasi dari para pegawai mengenai kondisi kerja mereka. Tetapi pada kenyataannya KORPRI sendiri kurang berperan aktif untuk menyalurkan aspirasi pegawai.

Berdasarkan penjelasan di atas, dapat disimpulkan bahwa pengelolaan SDM di instansi/organisasi pemerintahan memiliki ciri-ciri sebagai berikut.

- Sumber dana untuk operasional dan penggajian karyawan berasal dari APBN/ APBD

- Terdapat tunjangan-tunjangan di luar penggajian

- Struktur organisasi yang digunakan bersifat kaku dan birokratif sehingga pegawai kurang mendapatkan stimulasi untuk menyampaikan pendapatnya dan berpartisipasi dalam pengambilan keputusan.

- Pengelolaan SDM-nya berbasis pada kinerja dan kompetensi

- Kenaikan pangkat secara otomatis terjadi setiap 4 tahun sekali, dengan tahapan pengajuan kenaikan pangkat yang terbilang panjang dan kurang efisien

- Instansi pemerintah sulit untuk melakukan Pemutusan Hubungan Kerja bagi karyawan yang bermasalah dan tidak lagi produktif. Salah satu persyaratan PHK adalah apabila pegawai menjalankan hukuman penjara minimal 4 tahun.

- Dalam pengelolaan SDM, perturan pemerintah memiliki peran kuat dan langsung. 


\section{Pengelolaan SDM di Organisasi Non} Pemerintah

Organisasi ini adalah organisasi yang didirikan oleh perorangan ataupun sekelompok orang yang bertujuan untuk memperoleh keuntungan ataupun memberikan pelayanan kepada masyarakat umum (tanpa bertujuan memperoleh keuntungan) dari kegiatannya (Layanan Swadaya Masyarakat/LSM). Maka secara garis besar organisasi non pemerintah dapat di lihat dengan ciri sebagai berikut.

1. Organisasi ini bukan bagian dari pemerintah, birokrasi ataupun negara

2. Dalam melakukan kegiatan bertujuan untuk memperoleh keuntungan (nirlaba) atau untuk memberikan pelayanan kepada masyarakat umum tanpa mengharapkan keuntungan (non profit)

3. Organisasi non pemerintah dapat bergerak di berbagai bidang kehidupan. Seperti contohnya perbankan, hukum, manajemen dan lain-lain.

Berbeda dengan organisasi pemerintah, organisasi non pemerintah atau biasa disebut dengan organisasi swasta memiliki sumber dana untuk operasional perusahannya dari stakeholder atau pemegang saham. Stakeholder disini bisa 1 orang atau lebih. Bahkan beberapa organisasi swastapun sudah memiliki saham terbuka, dimana saham tersebut dapat dimiliki oleh masyarakat. Dalam pengelolaan SDMnya, biaya untuk operasional SDM dan penggajian karyawan berasal dari dana yang sudah direncanakan untuk divisi SDM tersebut setiap tahunnya. Nominal dana ini dirapatkan oleh jajaran direktur selaku manajemen perusahaan. Selain gaji yang rutin, ada juga bonus-bonus yang diberikan seperti bonus akhir tahun (diberikan sesuai dengan kontribusi karyawan pada perusahaan) dan tunjangan-tunjangan seperti kesehatan dan lain-lain.

Struktur organisasi pada perusahaan swasta ini biasanya lebih bervariasi dibandingkan dengan struktur yang ada di permerintahan. Walaupun begitu, pengelolaan SDM di perusahaan swasta ini juga memberikan penekanan pada kinerja karyawan. Sudah banyak organisasi non pemerintah yang melakukan penilaian kinerja karyawannya dengan cukup objektif. Penilaian ini akan mengacu kepada imbal jasa atau kenaikan pangkat yang akan diperoleh karyawan yang bersangkutan. Dengan prosedur yang dijalankan ini, dapat dikatakan bahwa akan lebih mudah memotivasi karyawan pada organisasi non pemerintah dari pada memotivasi karyawan pada organisasi pemerintah.

Untuk status karyawan hampir sama dengan organisasi pemerintah (ada yang tetap dan ada yang kontrak). Perbedaannya adalah, akan lebih mudah untuk melakukan Pemutusan Hubungan Kerja (PHK) pada karyawan perusahaan swasta karena biasanya perusahaan-perusahaan swasta memiliki prosedur penilaian kinerja yang ketat. Apabila terdapat pelanggaran kecil bisa jadi karyawan tersebut mendapat surat peringatan. Surat peringatan yang diberikan beberapa kali hingga limit tertentu dapat membuat si karyawan mengalami PHK. Alasan terjadinya PHK sebagian besar karena karyawan tersebut dianggap tidak memiliki dan tidak menunjukkan performa kerja yang baik.

Banyak hal-hal yang mempengaruhi pengelolaan SDM di organisasi swasta. Hal tersebut sudah dijelaskan sebelumnya. Faktor-faktor yang dapat mempengaruhi pengelolaan SDM di organisasi swasta antara lain seperti perkembangan teknologi, kebijakan pemerintah, Serikat Pekerja dan lain-lain.

Di jaman yang serba instan dan cepat ini, organisasi non-pemerintah harus mampu melakukan penyesuaian besar-besaran dan menjadi lebih fleksibel sehingga tidak tenggelam dalam persaingan. Berbeda dengan organisasi pemerintah, organisasi non pemerintah/swasta harus mampu bertahan dan terus berkembang, karena jumlah organisasi non permerintah juga semakin banyak. 
Secara garis besar, pengelolaan SDM di organisasi non pemerintah sama dengan pengelolaan SDM yang sudah dijelaskan sebelumnya. Pengelolaan SDM tersebut mencakup rekrutmen (recruitment), seleksi (selection), penempatan (placement), pelatihan dan pengembangan (training and development), penilaian kinerja (performance appraisal), pengembangan organisasi (organization develompent), perencanaan SDM (human resource planning), promosi dan mutasi karyawan (promotion and transfer) dan pemutusan hubungan kerja (PHK).

Berdasarkan penjelasan diatas, dapat disimpulkan bahwa pengelolaan SDM pada organisasi non pemerintah adalah:

- Sumber dana untuk operasional dan penggajian karyawan berasal dari Stakeholder atau pemegang saham

- Terdapat tunjangan-tunjangan di luar penggajian

- Struktur organisasi yang lebih bervariasi

- Pengelolaan SDM-nya berbasis pada kinerja dan kompetensi

- Kenaikan pangkat berdasarkan penilaian kinerja

- Dasar Pemutusan Hubungan Kerja lebih mudah dibangdingkan pada organisasi pemerintah.

Dalam pengelolaan, perturan pemerintah memiliki pengaruh, tetapi hal yang menjadi fokus utama lebih kepada bagaimana organisasi dapat bertahan di tengah persaingan.

\section{Perbandingan Organisasi Pemerintah dan Non Pemerintah (Swasta)}

Dari penjelasan sebelumnya, dapat dilihat bahwa terdapat persamaan dan perbedaan antara pengelolaan SDM di organisasi pemerintah dan organisasi non pemerintah. Persamaan antara pengelolaan SDM di organisasi pemerintah dan organisasi non pemerintah adalah garis besar proses pengelolaan yang bertujuan untuk meningkatkan efisiensi, efektivitas dari pelaksanaan tugas/pekerjaan, fungsi dan kewajiban tenaga kerja, yang meliputi perencanaan, pengadaan, pengembangan kualitas, penempatan, promosi, penggajian, kesejahteraan dan pemberhentian. Pengelolaan SDM ini juga sama-sama menekankan pada kinerja dan kompetensi yang dimiliki oleh masing-masing tenaga kerja.

Selain persamaan, terdapat juga perbedaan antara pengelolaan SDM di organisasi pemerintah dan pengelolaan SDM di organisasi swasta. Perbedaannya antara lain:

- Sumber dana dalam pelaksanaan pengelolaan SDM. Untuk organisasi pemerintah, sumber dana berasal dari dana APBN/APBD, sementara untuk organisasi swasta, sumber dana berasal dari pemegang saham.

- Struktur organisasi yang menaungi pengelolaan SDM juga terlihat berbeda. Sebagian besar organisasi pemerintah memiliki struktur organisasi yang kaku dan bersifat birokrasi, sementara bagi organisasi swasta, sifat dari struktur organisasinya lebih bervariasi. Kondisi struktur kerja yang kaku dan birokratis dapat memasung kreativitas berpikir dari tenaga kerja yang berkerja di dalam organisasi tersebut.

- Dalam hal kenaikan pangkat, organisasi pemerintah lebih menekankan pada lama bekerja (secara otomatis pangkat akan naik setelah 4 tahun). Sementara bagi organisasi swasta, kenaikan pangkat lebih pada penilaian kinerja. Dari sini dapat terlihat bahwa dalam rangka memotivasi kinerja pegawai organisasi pemerintah akan sulit dilakukan melalui prosedur kenaikan pangkat ini.

- Untuk proses Pemutusan hubungan kerja, akan lebih sulit bagi organisasi pemerintah untuk melakukan hal ini, karena walaupun 
karyawan sudah dianggap tidak lagi produktif, karyawan tersebut dapat diberikan semacam peringatan atau pelatihan. Akan sangat sulit bila harus memberhentikan tanpa adanya kesalahan yang sangat fatal. Sementara untuk organisasi swasta, akan lebih mudah melakukan pemutusan hubungan kerja apabila karyawan sudah diberikan surat peringatan beberpa kali (sesuai dengan jumlah dalam prosedur yang berlaku) karena tindak indisipliner atau kinerja yang kurang, maka perusahaan berhak untuk melakukan pemutusan hubungan kerja terhadap karyawan yang bersangkutan.

\section{DAFTAR PUSTAKA}

Dessler, G. (1997). Human Resources Management. Prentice Hall, New Jersey

Hadiat (2005). Membangkitkan Institusi Litbang () diakses Juni, 2008

Kepala Bagian Pemerintah Propinsi DKI Jakarta (2008). dalam kuliah Kapita Selekta dengan topik Pengelolaan SDM di Pemprov DKI Jakarta.

Kepala Biro Perencanaan dan Keuangan Badan Pemeriksa Obat dan Makanan, (2008).

Kleiman, L.S. (2000). Human Resources Management. South Western College Publishing.

Munandar A.S. (2001). Sumber Daya Manusia dalam Rangka Pembangunan Nasional. Bagian PIO Fakultas Psikologi Universitas Indonesia, Depok.
Munandar A.S. (2004). Psikologi Industri dan Organisasi. Bagian PIO Fakultas Psikologi Universitas Indonesia, Depok Nasution, M. (2000). Manajemen Personalia; Aplikasi dalam Perusahaan. Djambatan, Jakarta.

Thornton, G.C. (1992). Assessment Centers in Human Resources Management. Addison-Wesley Publishing Company, Colorado. 